\title{
Distribution and occurrence of trace elements in the No.14 coal from the Huolinhe mine
}

\author{
Xiangfei Bai ${ }^{1}$ (1) $\cdot$ Yue Wang ${ }^{2,3} \cdot$ Wenhua $\mathrm{Li}^{4}$
}

Received: 1 September 2016/Revised: 17 April 2017/Accepted: 5 July 2017/Published online: 26 July 2017

(C) The Author(s) 2017. This article is an open access publication

\begin{abstract}
Optical microscopy, and scanning electron microscopy in conjunction with energy dispersed X-ray spectrometry (SEM-EDX), have been used to study the minerals and the concentrations of 12 trace elements in the No.14 coal from the Huolinhe mine, Inner Mongolia China. The distribution, affinity and removability of the trace elements were studied by float-sink experiments and petrological methods. A high mineral content, dominated by clay minerals, was found in the No.14 coal from the Huolinhe mine. The concentrations of $\mathrm{As}, \mathrm{Sb}$ and $\mathrm{Hg}$ are relatively high compared to the average values for Chinese coals. As, $\mathrm{Cr}, \mathrm{Hg}, \mathrm{Li}, \mathrm{Mn}, \mathrm{Pb}$ are mainly associated with the minerals while $\mathrm{Cd}, \mathrm{Co}, \mathrm{Ni}, \mathrm{Sb}$, and $\mathrm{Se}$ are evenly distributed between the minerals and the organic matter. Be and $\mathrm{Ba}$ are mainly distributed in the minerals with a minor proportion in the organic matter. Most elements have a low organic affinity, although $\mathrm{Sb}, \mathrm{Se}, \mathrm{Co}, \mathrm{Cd}, \mathrm{Ni}$ are closely integrated with the organic matter. High theoretical removabilities are indicated for most trace elements. So it may be possible to lower the concentrations of trace elements during coal preparation.
\end{abstract}

Keywords Trace elements $\cdot$ Modes of occurrence $\cdot$ Organic affinity $\cdot$ Removability $\cdot$ Huolinhe coal

\section{Introduction}

The geochemistry of trace elements in coals is an important part of coal science. The scientific evaluations of concentrations of trace elements in coals are the solid foundations of evaluation the environmental impacts on harmful elements and the utilization of valuable elements for industry (Reed et al. 2001; Bai 2003; Dai et al. 2005, 2012). The modes of occurrence of trace elements include two aspects:

Xiangfei Bai

bxf1970@sina.com

1 College of Environmental Engineering, North China Institute of Science and Technology, Beijing 101601, China

2 Beijing Research Institute of Coal Chemistry, China Coal Research Institute, Beijing 100013, China

3 State Key Laboratory of Coal Mining and Clean Utilization, Beijing 100013, China

4 National Institute of Clean-and-Low-Carbon Energy, Beijing 102209, China one is concerned with the concentration and distribution of trace elements in minerals and macerals, which may in turn influence the behavior of trace elements in coal preparation; the other is concerned with how the trace elements occur within their carriers (e.g. organically-bonded, microfine minerals, occurrence in an adsorbed state), which may of importance of the behavior of the trace elements in coal conversion and utilization processes. Identification of the modes of trace elements in coal is limited by the heterogeneity of the mineral and organic components, and only broad interpretations can usually be made. Indirect analytical techniques,such as float-sink methods, single component analysis, sequential chemical extraction (SCEE), low temperature ashing combined with XRD (LTA-XRD), and various statistical methods, do not really provide direct evidence of the distribution of trace elements. Other techniques, such as microprobe (electron probe, ion probe and X-ray probe) and spectroscopy methods (e.g. X-ray absorption fine structure spectrum (XAFS)) are time consuming for quantitative analysis of the samples as a whole. 
The results from different analytical methods may also contradict each other and even so the understanding developed may have low confidence levels (Finkelman 1994). The macerals and minerals in coal, however, combine to host the various trace elements in coal, and thus it may be possible to identify the distributions of particular elements and discuss the possible combinations involved.

Research on minimizing possible hazards associated with trace elements is an important part of coal utilization technology. It may therefore be possible to reduce the environmental impacts associated with trace elements if the concentrations of key trace elements in coal are reduced by coal preparation technology (Senior et al. 2000). It is useful to subject a series of samples of different petrographic (mineral and maceral) characteristics by float-sink studies to learn more about the modes of trace element occurrence. Float-sink separation has been used in a number of studies to evaluate the partitioning of individual trace elements between organic-rich and mineral-rich fractions of coal samples, based mainly on correlations between element concentration on factors such as separation density and ash yield. The contents of trace elements in organic and inorganic components were studied by many researchers in this way (Gluskoter et al. 1977; Solari et al. 1989; MartinezTarazona et al. 1992; Pires et al. 1997; Klika et al. 1997; Klika and Kolonaznik 2000; Querol et al. 2001; Wagner and Tlotleng 2012; Oliveira et al. 2013; Equeenuddin et al. 2016; Bai et al. 2017). The effectiveness of float-sink separation of partitioning individual elements and identifying any element "affinities" are limited by the particle size at which the separation is carried out as mineral particles may still be present in the low-density fraction, even in a finely-ground coal. Although partitioning indicated at fine particle size (e.g. in the laboratory) is also not necessarily reproduced when coals are separated from coarser particle sizes in industrial preparation plants, it is still effective to evaluate the organic affinities and potential removability of particular trace elements (Bai et al. 2002; Tang et al. 2005; Wang and Li 2007; Song et al. 2010; Bai et al. 2014). It is worth noting that the reject materials from coal preparation of such cases may become even more enriched in the same trace elements, so that preparation may simply move the environmental impacts on the utilization plant to the waste disposal site.

The Huolinhe coalfield is part of the BayinheshuoErenhot basin of Inner Mongolia (Mao and Xu 1999). Located in a graben structure of the southern section of the Daxinganling mountain ridge, it was formed in the Late Jurassic-early Cretaceous period. About 70 million tonnes of commercial coal were produced in 2015, mainly supplied to Northeast China for power generation. However, the Huolinhe coal failed to meet the requirements of long distance transportation (More than $600 \mathrm{~km}$ ) when Interim Measures on Managements of Commercial Coal Quality has been put into act since 1 Jan. 2015 in China. The ash yield was beyond the upper limit while the calorific value was under the floor level. It is in great need for an industry coal preparation plant to lower the ash yield and sulfur content and increase the caloric value.

In this study, optical microscopy, and scanning electron microscopy in conjunction with energy dispersed X-ray spectrometry (SEM-EDX), were used to study the individual minerals in the No.14 coal from the Huolinhe mine. Then the float-sink experiments were conducted. The modes of occurrence of trace elements were discussed by correlation analysis and the inferred concentrations of trace elements in organic matters and minerals were then calculated based on linear regression. The organic affinities and removabilities of trace elements were evaluated to provide a comprehensive scene of trace elements behavior in coal preparation.

\section{Experiments}

\subsection{Sampling and experiments}

\subsubsection{Sampling}

The run-of-mine samples were systematically collected of the No.14 coal seam following ISO standard (ISO 18283:2006 Hard coal and coke-manual sampling). In consideration of the need of float-sink experiments, the samples collected were combined as one. Then the samples were divided into two parts equally, one for the chemical analyses and the petrographic studies, the other for floatsink experiments.

\subsubsection{Float-sink experiments}

The float-sink experiments can predict the behavior in industry plant. In the coal preparation, the individual minerals particles, which are always visible from optical microscopy, were mainly removed while the minerals associated with the organic matters can't be liberated. The particle sized between $3 \mathrm{~mm}$ and $0.5 \mathrm{~mm}$ are proper range for the research on the removal of individual minerals.

The coal samples used for float-sink experiments were crushed to less $3 \mathrm{~mm}$ and fine particles of less than $0.5 \mathrm{~mm}$ were collected. Float-sink experiments were conducted using particles sized between $3 \mathrm{~mm}$ and $0.5 \mathrm{~mm}$ following the Chinese standard GB/T478-2008. Five densities levels, i.e. $1.30,1.40,1.50,1.60,1.80 \mathrm{~g} / \mathrm{cm}^{3}$ were used. The medium used were $\mathrm{ZnCl}_{2}$ (analytically pure). 
Table 1 Basic characteristics of the coal studied

\begin{tabular}{|c|c|c|c|c|c|c|c|c|c|}
\hline \multicolumn{5}{|c|}{ Proximate analysis (wt\%) } & \multicolumn{5}{|c|}{ Ultimate analysis $(\mathrm{wt} \%)$} \\
\hline$M_{\mathrm{ar}}$ & $M_{\mathrm{ad}}$ & $A_{\text {ad }}$ & $V_{\text {ad }}$ & $\mathrm{FC}_{\mathrm{ad}}$ & $\mathrm{C}_{\mathrm{daf}}$ & $\mathrm{H}_{\mathrm{daf}}$ & $\mathrm{N}_{\mathrm{daf}}$ & $\mathrm{O}_{\mathrm{daf}}$ & $\mathrm{S}_{\mathrm{daf}}$ \\
\hline 34.0 & 17.38 & 21.12 & 29.78 & 31.72 & 73.11 & 4.70 & 1.22 & 20.22 & 0.75 \\
\hline \multirow[b]{2}{*}{$\mathrm{S}_{\mathrm{t}, \mathrm{d}}$} & \multicolumn{3}{|c|}{ Forms of sulfur } & \multicolumn{4}{|c|}{ Maceral group (vol\%) } & $R_{\mathrm{o}, \max }(\%)$ & $Q_{\text {net,ar }}$ \\
\hline & $\mathrm{S}_{\mathrm{p}, \mathrm{d}}$ & $\mathrm{S}_{\mathrm{s}, \mathrm{d}}$ & $\mathrm{S}_{\mathrm{o}, \mathrm{d}}$ & Huminite & Inertinite & Liptinite & Mineral & & $(\mathrm{MJ} / \mathrm{kg})$ \\
\hline 0.56 & 0.06 & 0.04 & 0.46 & 76.3 & 6.1 & 2.1 & 15.6 & 0.33 & 12.77 \\
\hline \multicolumn{10}{|c|}{ Ash composition (wt $\%)$} \\
\hline $\mathrm{SiO}_{2}$ & $\mathrm{Al}_{2} \mathrm{O}_{3}$ & $\mathrm{Fe}_{2} \mathrm{O}_{3}$ & $\mathrm{CaO}$ & $\mathrm{MgO}$ & $\mathrm{SO}_{3}$ & $\mathrm{TiO}_{2}$ & $\mathrm{P}_{2} \mathrm{O}_{5}$ & $\mathrm{Na}_{2} \mathrm{O}$ & $\mathrm{K}_{2} \mathrm{O}$ \\
\hline 65.22 & 19.68 & 4.94 & 3.95 & 0.63 & 0.21 & 0.70 & 0.06 & 0.64 & 1.60 \\
\hline
\end{tabular}

\subsubsection{The precision of the float-sink experiment}

The precisions of the float-sink experiments and the determination of the trace elements were evaluated by balancing the trace elements concentration of the raw coal and the weighted mean values in the products of different densities in float-sink experiments and in fines of particle size less than $0.5 \mathrm{~mm}$. The calculation was conducted according to Eq. (1) according to the Chinese standard GB/ T478-2008:

$R=\sum_{j=1}^{n} C_{j} W_{j} / C$

where, $R$ is the ratio of the weight mean concentration of trace element in the products of different densities and of that in raw coal (\%), $C$ is the concentration of trace elements in the raw coal $(\mu \mathrm{g} / \mathrm{g}), C_{j}$ is the concentration of trace elements in the products of a certain density including the fines of particle size less than $0.5 \mathrm{~mm}(\mu \mathrm{g} / \mathrm{g}), W_{j}$ is the yield of products of certain density including the fines of particle size less than $0.5 \mathrm{~mm}(\%)$.

\subsection{Determinations}

Proximate analysis, ultimate analysis, total sulfurs, forms of sulfur, calorific value, ash composition and petrographic studies were conducted of the bulk material. The concentrations of As, $\mathrm{Ba}, \mathrm{Be}, \mathrm{Cd}, \mathrm{Co}, \mathrm{Cr}, \mathrm{Hg}, \mathrm{Mn}, \mathrm{Ni}, \mathrm{Pb}, \mathrm{Sb}$, Se in the No.14 coal seam were determined. The ash and sulfur contents, the maceral groups and minerals (divided into clay mineral, pyrite, quartz and carbonates) and concentrations of the trace elements mentioned above were determined in different densities fractions and in the fines of particle size less than $0.5 \mathrm{~mm}$ from the float-sink experiments.

Total moisture was determined following ISO 589:2003 (Hard coal- determination of total moisture). The proximate analyses of the samples were determined according to ISO 11722:1999 (Determination of moisture in the general analysis test sample by drying in nitrogen), ISO 1171:1997 (Determination of ash) and ISO 562:1998 (Determination of volatile matter). Total sulfurs of the samples were determined according to ISO 351:1996 (Determination of total sulfur-High temperature combustion method). Forms of sulfur in coal were determined according to ISO 157:1996 (coal-Determination of forms of sulfur). Calorific values were determined according ISO 1928:1995 (Solid mineral fuels-Determination of gross calorific value by the bomb calorimetric method and calculation of net calorific values). Ash compositions were determined according to GB/T 1574-2007 (Test method for analysis of coal ash). Ultimate analyses were determined according to ISO 625:1996 (Solid mineral fuels-Determination of carbon and hydrogen-Leibig method) and ISO 333:1996 (Coal-determination of nitrogen). The reflectance of vitrinite and maceral groups were determined according to ISO 7404:2009 (Method for the petrographic analysis of coals) using ZEISS AXIOSKOP 40 optical microscope.

Optical characteristics of minerals were described and photographs were taken with petrographic samples. A scanning electron microscope in conjunction with an energy-dispersive X-ray spectrometer (SEM-EDX) was used to study the characteristics of the minerals by spot and area scanning. The backscattered electron images (BSE) of minerals were then taken. Mineral compositions were determined by EDX both qualitatively and quantitatively. The acquisition time of EDX analysis was $50 \mathrm{~s}$, and the scanning areas were determined by the size and morphology of mineral particles.

The concentrations of trace elements were determined using minus 200-mesh samples. The trace elements were determined by inductively coupled-plasma mass spectrometry (ICP-MS) except for As, $\mathrm{Hg}, \mathrm{Sb}$ and Se. For ICPMS analysis the samples were digested using a microwave 

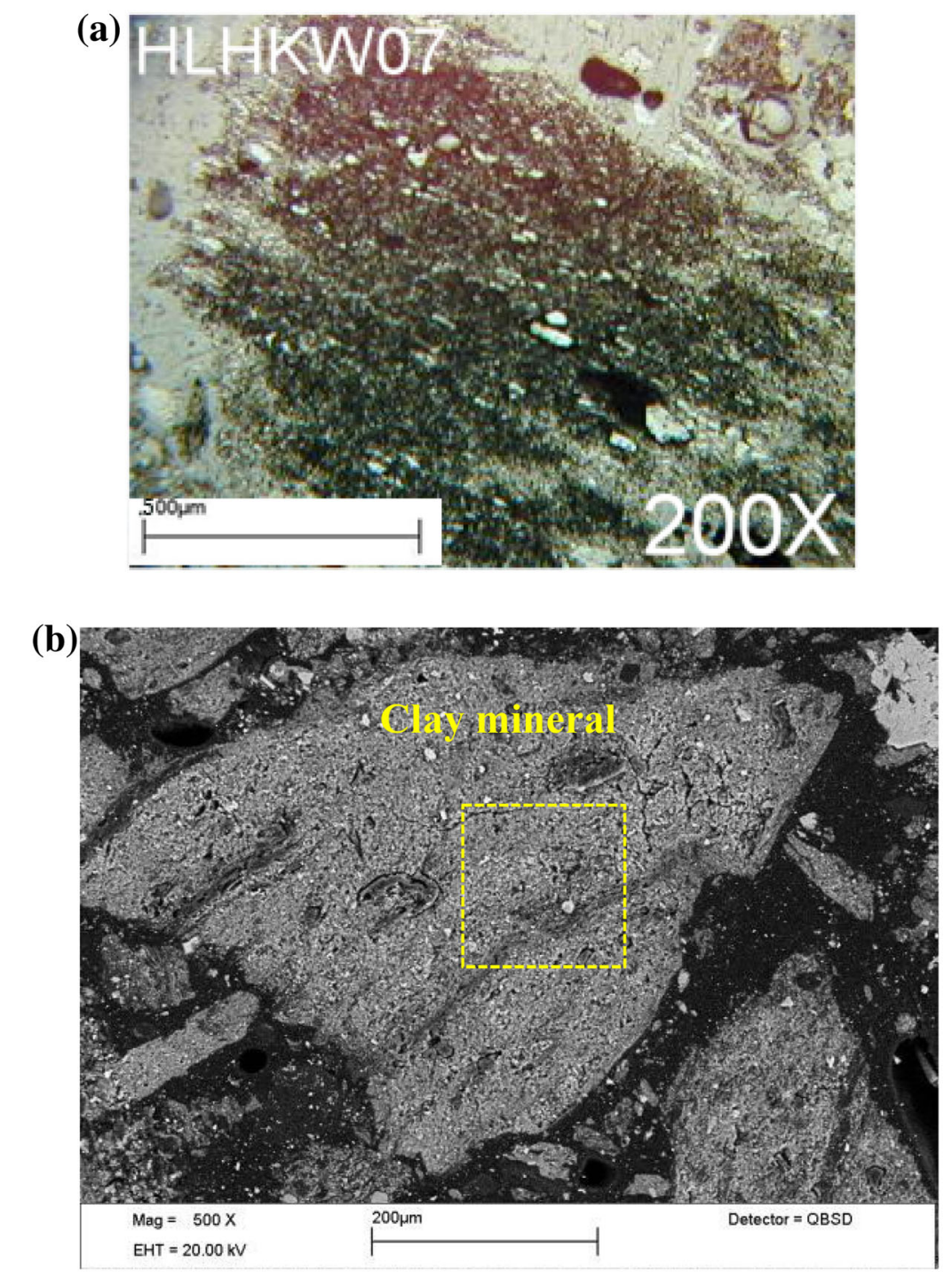

(c)

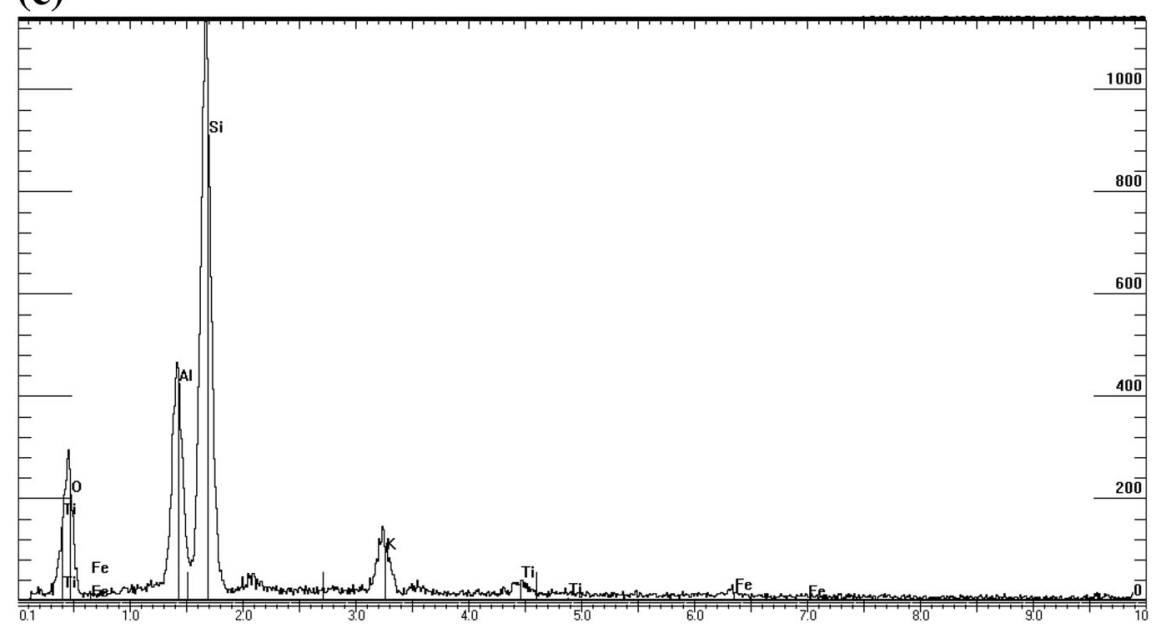

Fig. 1 Clay minerals in the Huolinhe coal. a Optical microscopy, reflected light; air; polarized light;200×. b SEM backscattered electron image. c X-ray energy spectrum diagram of the box in b, scanning area: $150 \mu \mathrm{m} \times 150 \mu \mathrm{m}$ 
Table $2 \mathrm{Si} / \mathrm{Al}$ ratio of the clay minerals

\begin{tabular}{lllll}
\hline $\begin{array}{l}\text { Clay } \\
\text { mineral }\end{array}$ & $\begin{array}{l}\text { Sample } \\
\text { no. }\end{array}$ & $\begin{array}{l}\text { Scanning area } \\
(\mu \mathrm{m} \times \mu \mathrm{m})\end{array}$ & $\begin{array}{l}\text { Acquisition } \\
\text { time(s) }\end{array}$ & $\begin{array}{l}\text { Si/Al } \\
\text { ratio }^{\mathrm{a}}\end{array}$ \\
\hline Type 1 & 1 & $150 \times 150$ & 50 & 2.58 \\
& 2 & $100 \times 100$ & 50 & 3.75 \\
& 3 & $100 \times 100$ & 50 & 2.97 \\
& 4 & $100 \times 100$ & 50 & 2.70 \\
& 5 & $100 \times 50$ & 50 & 2.92 \\
& 6 & $100 \times 100$ & 50 & 2.56 \\
Type 2 & 7 & $200 \times 200$ & 50 & 1.45 \\
& 8 & $60 \times 60$ & 50 & 1.57 \\
\hline
\end{tabular}

a Inferred element abundance

high pressure reactor. Hydride generation atomic fluorescence spectrometry analysis (HGAFS) was used to determine the concentrations of As, Sb and Se while cold-vapor atomic fluorescence spectrometry analysis (CVAFS) was used to determine the concentration of $\mathrm{Hg}$.

\subsection{Occurrences of the trace elements}

\subsubsection{Correlation analyses}

The correlation analyses between the trace element concentration and the organic matter, the minerals, the ash yield, and the sulfur content of the float-sink experiments were conducted. The correlation analyses among the trace elements of the float-sink experiments were conducted.

\subsubsection{The inferred concentrations of trace elements in organic matter and minerals}

The Huolinhe coal could be divided into organic matters and minerals in terms of coal petrology. The mass fraction of organic matter and the minerals in the raw coal and the products of different densities can be calculated according to Parr formula (Ward 2002) and shown in Eqs. (2) and (3).

$\mathrm{MM}=1.1 A_{\mathrm{d}}+0.5 \mathrm{~S}_{\mathrm{p}, \mathrm{d}}$

$\mathrm{ORG}=100-\mathrm{MM}$

where, MM is the mineral content of the coal (mass fraction), ORG is the organic matter in the coal (mass fraction), $A_{\mathrm{d}}$ is the yield of ash in the coal (\%), $\mathrm{S}_{\mathrm{p}, \mathrm{d}}$ is the pyritic sulfur content of the coal (\%).

A linear relationship was found for the trace element concentration of the raw coal $\left(C_{m}\right)$ and for the different macerals and minerals $\left(C_{m i}\right)$. The theoretical trace element $\left(C_{m i}\right)$ concentration of the macerals and the minerals was calculated by linear regression of the maceral and mineral compositions $\left(W_{m i}\right)$. The inferred concentrations of trace element $\left(C_{m i}\right)$ in the organic matter and the minerals were determined using Eq. (4) (Solari et al. 1989):

$C_{m}=\sum_{i=1}^{n} C_{m i} W_{m i}$

where, $C_{m}$ is the concentration of a specific element in the coal $(\mu \mathrm{g} / \mathrm{g}), C_{m i}$ is the inferred concentrations of a specific element in organic matters and in the minerals $(\mu \mathrm{g} / \mathrm{g})$, and $W_{m i}$ is the maceral composition of the products of different densities $(\%)$.

The amount of trace elements in the organic matter of the coal can be expressed by organic affinity. The organic affinity index $\left(A_{\mathrm{o}}\right)$ of different trace elements in the coal was calculated using Eq. (5) (Bai 2003):

$A_{\mathrm{o}}=C_{\mathrm{o}} W_{\mathrm{o}} / C$

where, $C_{\mathrm{o}}$ is the concentration of a specific trace element in the organic matter $(\mu \mathrm{g} / \mathrm{g}), C$ is the concentration of trace elements in the raw coal $(\mu \mathrm{g} / \mathrm{g})$, and $W_{\mathrm{o}}$ is the content of organic matter in the coal (mass fraction).

\subsubsection{Removability of the trace elements}

The theoretical removability of trace element, which is the ratio of trace element concentration in waste coal to that in the raw coal, depends both on the organic affinity and on fine coal recovery. Suitable separation density and trace element removability were obtained by float-sink experiments. The theoretical degree of trace element removal from the coal preparation can be calculated using Eq. (6) (Bai 2003).

$\lambda=\left(C-C_{\mathrm{r}} \times F C R\right) / C$

where, $\lambda$ is the theoretical removability of trace element (\%), $C$ is the concentration of trace element in the raw coal $(\mu \mathrm{g} / \mathrm{g}), C_{\mathrm{r}}$ is the concentration of trace element in the clean coal $(\mu \mathrm{g} / \mathrm{g})$, FCR is the fine coal recovery $(\%)$.

\section{Results and discussion}

\subsection{The characteristics of No.14 coal from huolinhe mine}

\subsubsection{The characteristics of the raw coal}

The results of the raw coals are listed in Table 1. The Huolinhe coal is a low-rank B with moderately high ash yield according to ISO standard 11760 . The sulfur content is low and dominated by organic sulfur. The $\mathrm{SiO}_{2}$ content is high while $\mathrm{Al}_{2} \mathrm{O}_{3}$ is relatively low in the ash. The huminite group is the dominant maceral group, while the proportions of inertinite and liptinite group are low. 
(a)

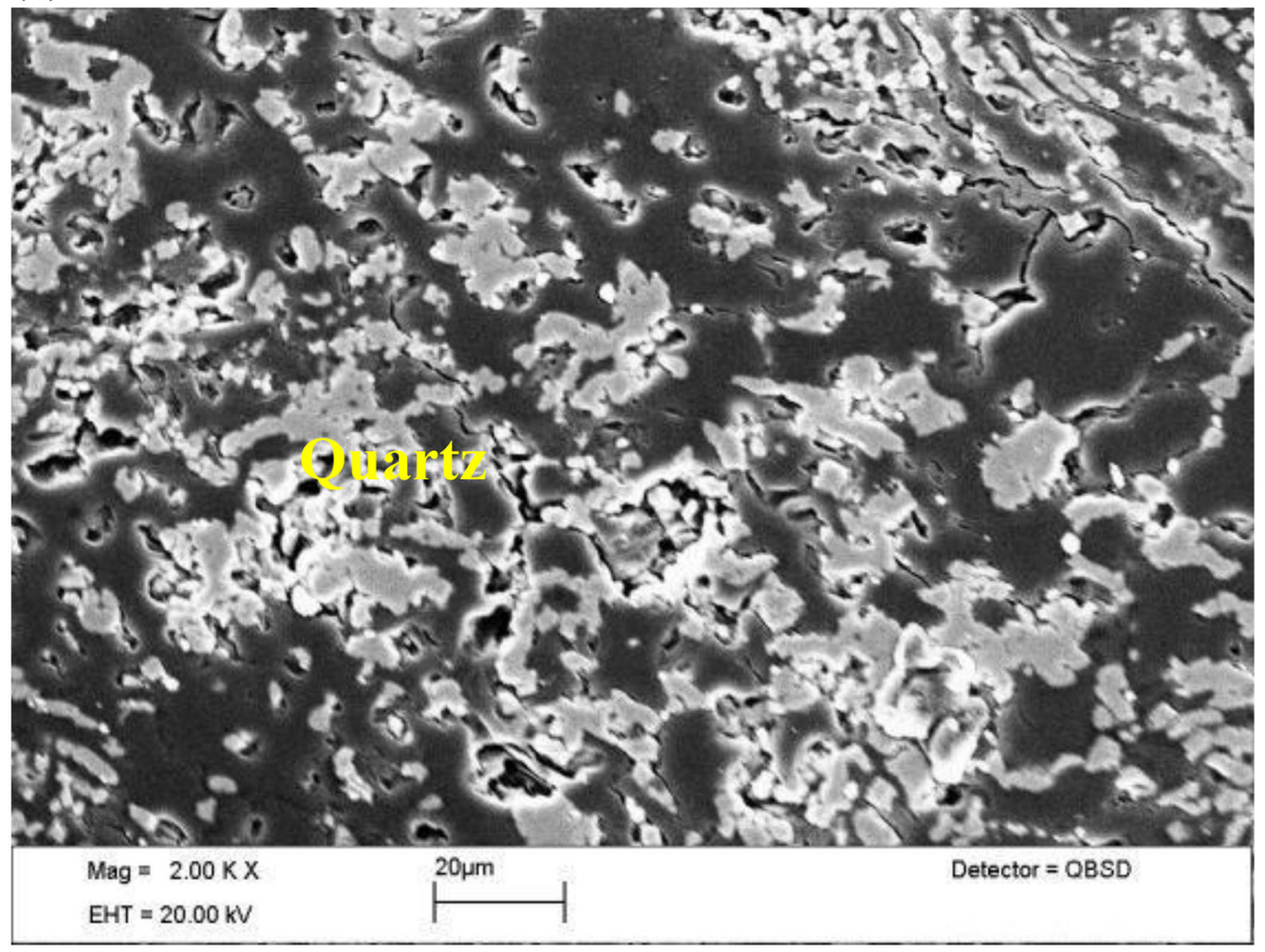

(b)

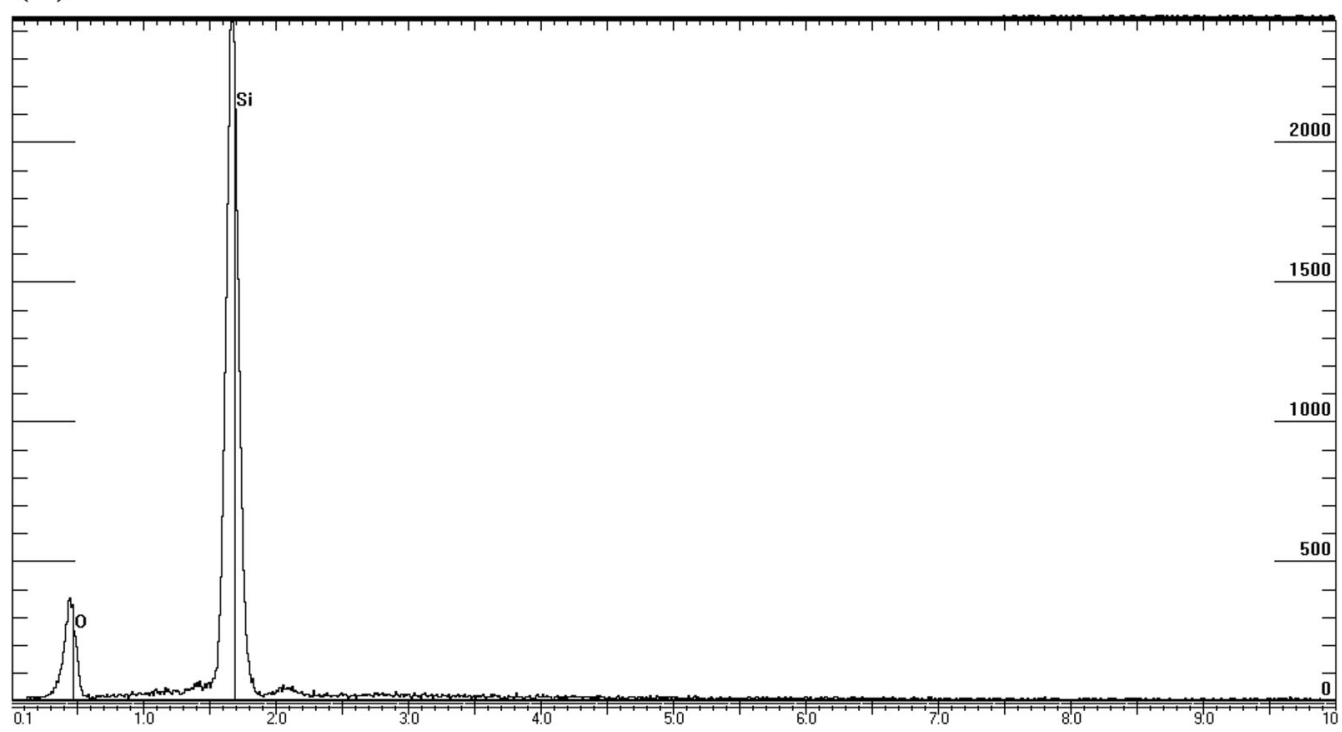

Fig. 2 Quartz in fusinite lumens. a SEM backscattered electron image. b X-ray energy spectrum diagram, spot scan

\subsubsection{Mineralogical compositions of No.14 coal from Huolinhe mine}

As the main minerals in Huolinhe coal, Clay minerals are mainly present as individual particles (Fig. 1) and also intimately intergrown with the organic components. It is uneven and has a black-brownish color in reflected light. The clay minerals can be divided into two types according to the $\mathrm{Si} / \mathrm{Al}$ ratio in $\mathrm{SEM}$. The $\mathrm{Si} / \mathrm{Al}$ ratio of type 1 is above 2 while that of type 2 is between 1.2 and 1.6 (Table 2). It is easy to distinguish quartz from the clay minerals in BSE modes of SEM as the secondary electron compositions of 


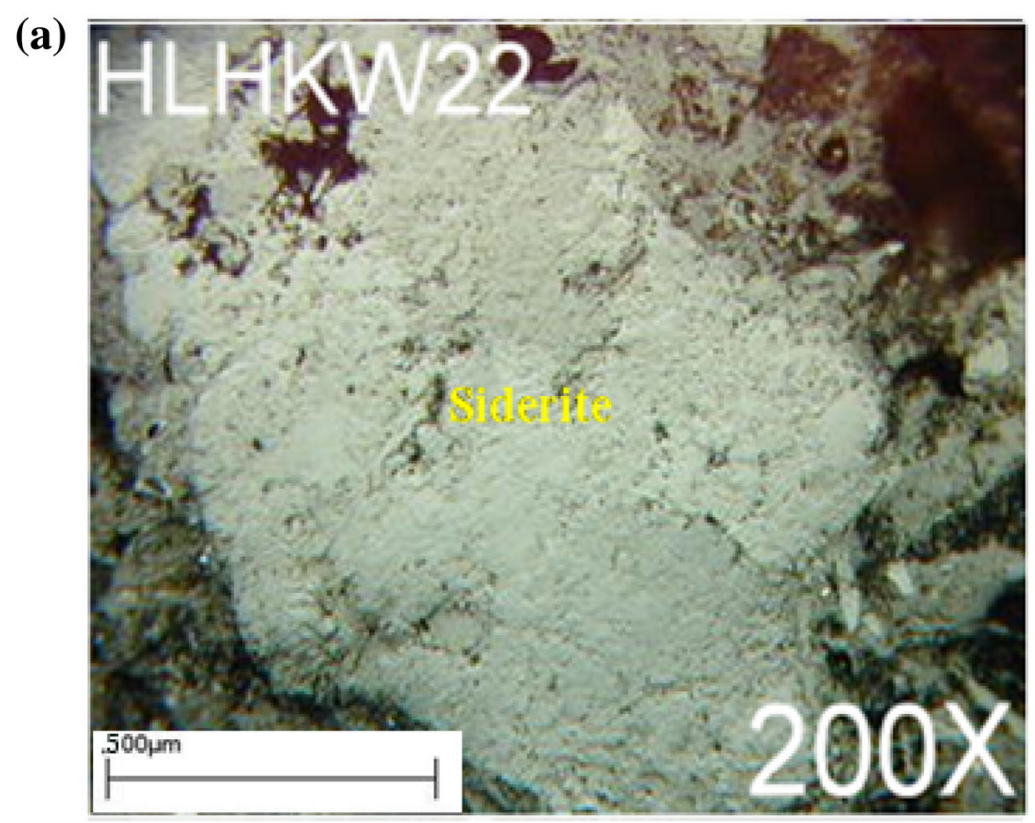

(b)

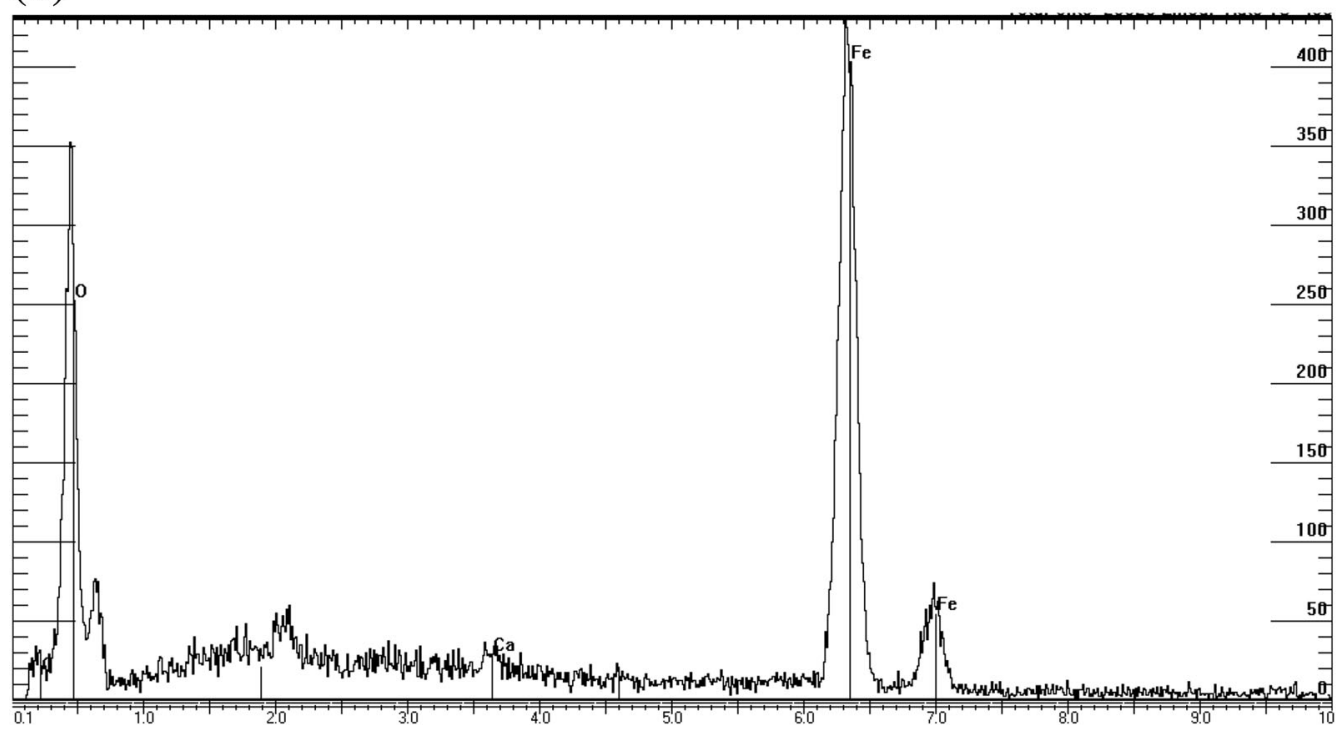

Fig. 3 Siderite in the Huolinhe coal. a Optical microscopy, reflected light; air; polarized light;200×. b X-ray energy spectrum diagram scanning area: $100 \mu \mathrm{m} \times 100 \mu \mathrm{m}$

the two minerals are different. It is interesting to note that the reflected colors of clay minerals in optical microscopy are related to its $\mathrm{Si} / \mathrm{Al}$ ratio by comparison the characteristics of clay minerals in optical microscopy and SEM. Generally, particles of high contents of Al demonstrate grayish-green while particles of low $\mathrm{Al}$ are black in optical microscopy.

The quartz occurs mainly as clastic fragments distributed in huminite and clay minerals, with a few occurrences in fusinite lumens (Fig. 2). The proportion of carbonate minerals is relatively low in the Huolinhe coal, and the carbonates are dominated by siderite with low proportions of calcite. The siderite is mainly in irregular shape (Fig. 3) with some having a microcrystalline aggregate form. With a relatively even surface in reflected light, the siderite is grey with internal reflection. Dim gray interference colors and four extinction positions are found in cross-polarized light. A few hematite particles are found in the Huolinhe coal, which may be oxidation products of siderite or pyrite. With an uneven surface and white reflected-light color, hematite appears under the SEM also to have $\mathrm{Mg}$ and $\mathrm{Ca}$ components (Fig. 4). $\mathrm{C}, \mathrm{Mg}$ and $\mathrm{Fe}$ 

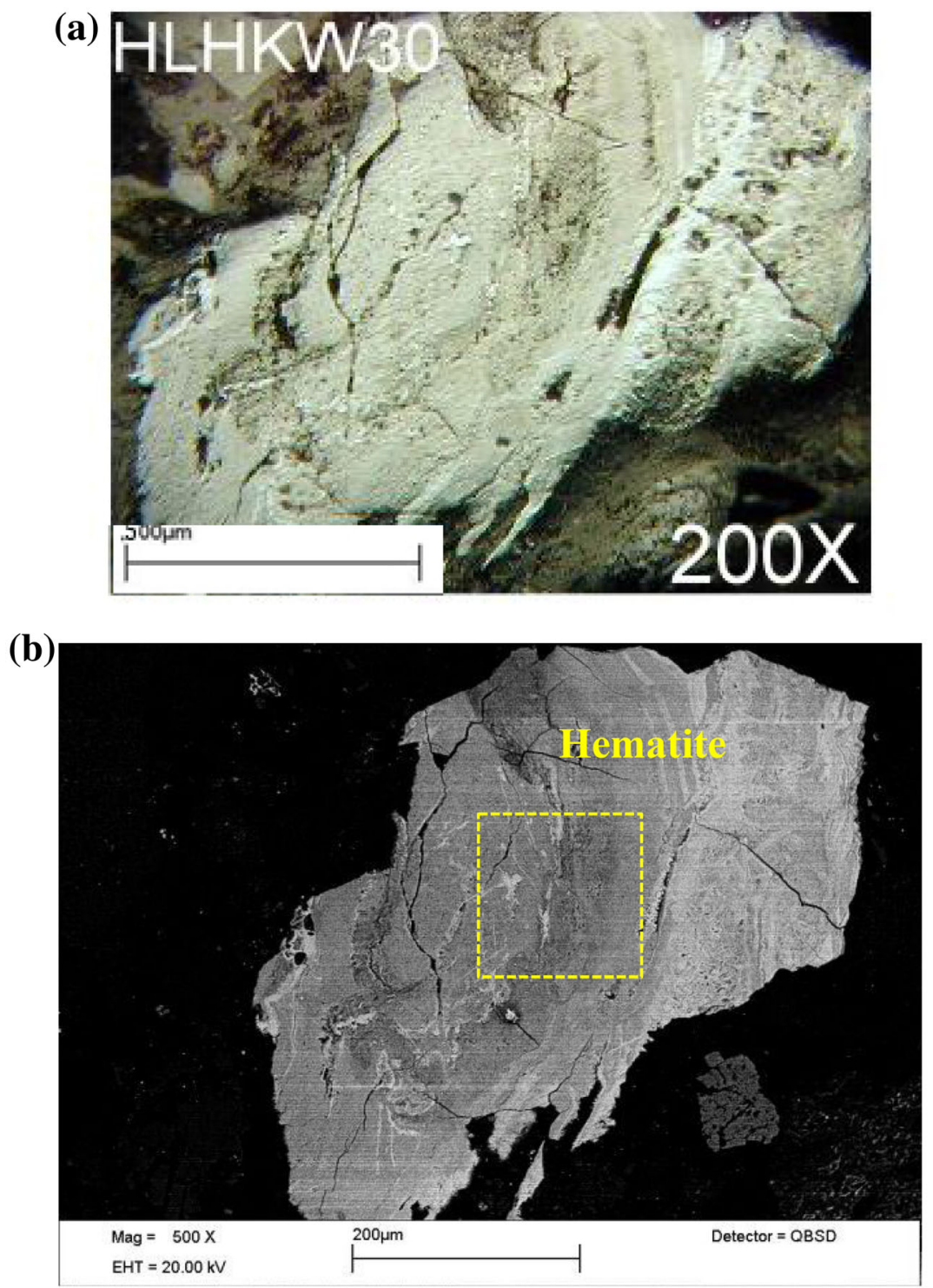

(c)

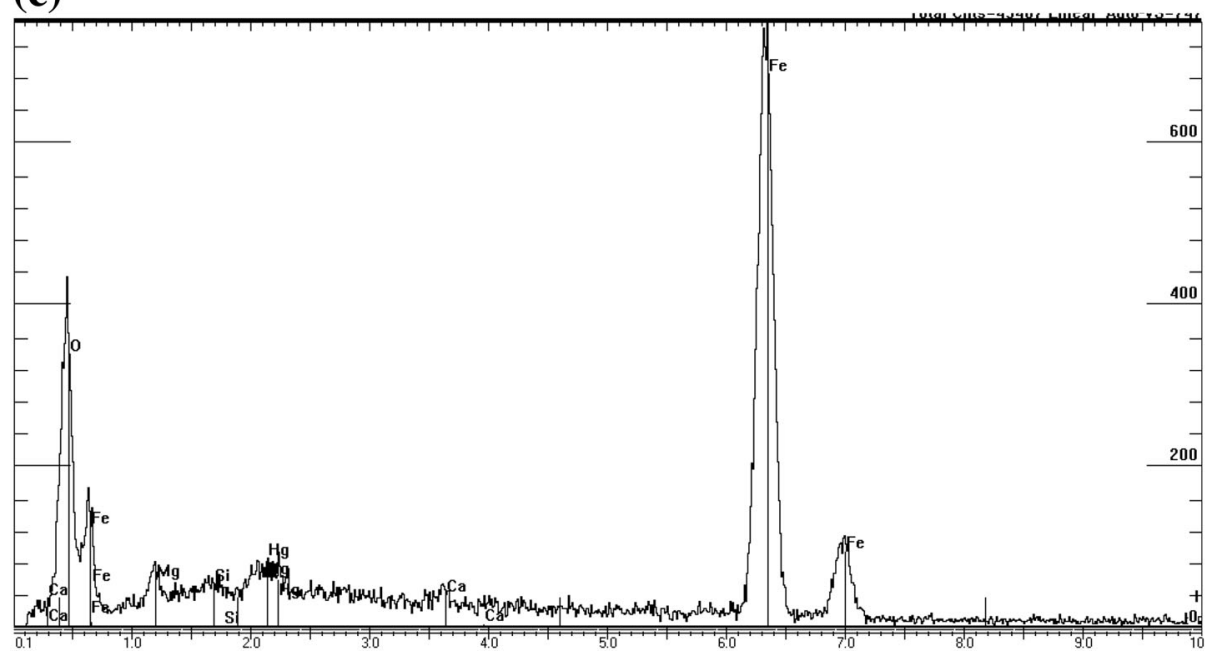

Fig. 4 Hematite in the Huolinhe coal. a Optical microscopy, reflected light; air; polarized light;200×. b SEM backscattered electron image. c Xray energy spectrum diagram of box in $\mathbf{b}$, scanning area: $150 \mu \mathrm{m} \times 150 \mu \mathrm{m}$ 
Table 3 Element concentrations in No.14 coal from Huolinhe mine $(\mu \mathrm{g} / \mathrm{g})$

\begin{tabular}{lcll}
\hline Element & Concentration & China coals $^{\mathrm{a}}$ & World low-rank coals $^{\mathrm{b}}$ \\
\hline $\mathrm{As}$ & 23.20 & 4.09 & 7.6 \\
$\mathrm{Ba}$ & 248.00 & 270 & 150 \\
$\mathrm{Be}$ & 1.47 & 1.75 & 1.2 \\
$\mathrm{Cd}$ & 0.09 & 0.81 & 0.24 \\
$\mathrm{Co}$ & 3.14 & 10.62 & 4.2 \\
$\mathrm{Cr}$ & 18.50 & 16.94 & 15 \\
$\mathrm{Hg}$ & 0.250 & 0.154 & 0.10 \\
$\mathrm{Mn}$ & 186.00 & $271.22^{\mathrm{c}}$ & 100 \\
$\mathrm{Ni}$ & 4.56 & 14.44 & 9.0 \\
$\mathrm{~Pb}$ & 9.08 & 16.64 & 6.6 \\
$\mathrm{Sb}$ & 2.97 & 0.71 & 0.84 \\
$\mathrm{Se}$ & 1.00 & 2.82 & 1.0 \\
\hline
\end{tabular}

a Bai et al. (2007)

b Ketris and Yudovich (2009)

c Ren et al. (1999)

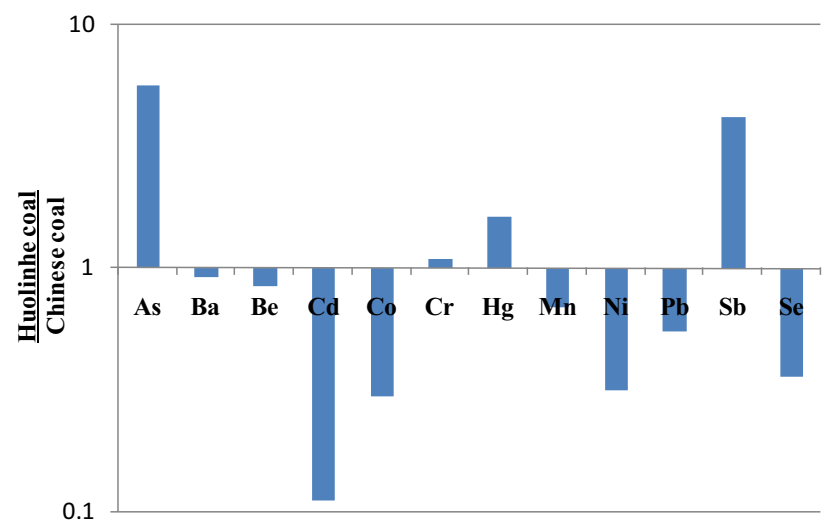

Fig. 5 Comparisons between the concentrations of trace elements in Huolinhe coal and those in Chinese coals

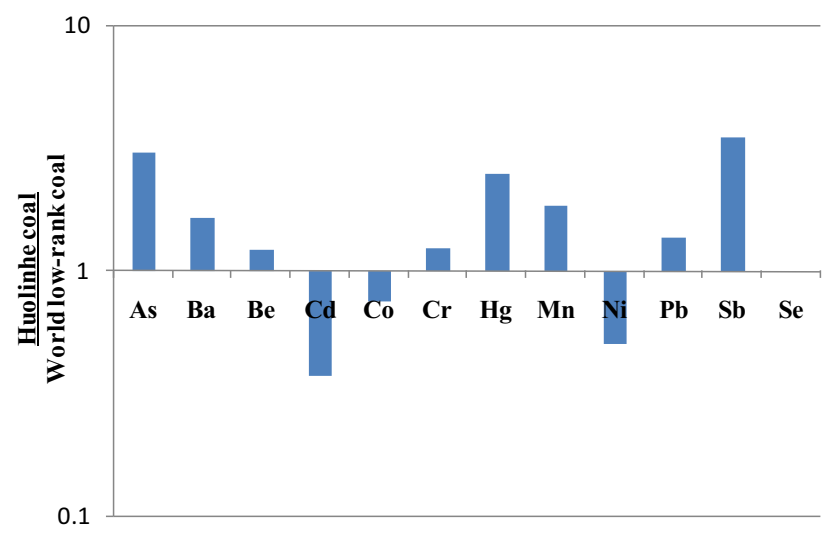

Fig. 6 Comparisons between the concentrations of trace elements in Huolinhe coal and those in world low-rank coals commonly distributed in the macerals or the pore water of lower-rank coals, and the $\mathrm{Fe}-\mathrm{Ca}-\mathrm{Mg}$ combinations may also be derived from drying out of pore water within the maceral components (Li et al. 2010).

\subsubsection{Concentrations of trace elements}

The concentrations of 12 trace elements in No.14 coal from Huolinhe mine were compared to average values of these trace elements in Chinese and world low-rank coals and the data are listed in Table 3 and Figs. 5, 6. Compared to the average values of trace elements in Chinese coals, the concentration of the trace elements in Huolinhe coal is relatively low. The concentrations of $\mathrm{As}, \mathrm{Sb}$ and $\mathrm{Hg}$ are 1.5-5 times higher than the averages for those elements in Chinese coals, while the concentrations of $\mathrm{Cr}$ and $\mathrm{Ba}$ are almost the same as the respective average concentrations in Chinese coals. The concentrations of the other trace elements are lower than those in Chinese coals. Compared to the average values of trace elements in world low-rank coals, the concentrations of $\mathrm{Sb}, \mathrm{As}, \mathrm{Hg}, \mathrm{Mn}, \mathrm{Ba}$ are 1.5-3.5 times higher than the averages for those elements in world low-rank coals. The concentrations of $\mathrm{Pb}, \mathrm{Cr}, \mathrm{Be}, \mathrm{Se}$ are slightly higher than the averages for those elements in world low-rank coals. The concentrations of other trace elements are lower than those in the world low-rank coals.

\subsection{The distributions of trace elements in float-sink experiments}

The maceral compositions and the concentrations of 12 trace elements in the products from the float-sink experiments are listed in Table 4. The precision of the float-sink experiment was in accordance with GB/T 478-2008, as shown by the balanced ash and sulfur content calculations. The $\mathrm{R}$ values of most trace elements were between $50 \%$ and $150 \%$, which are acceptable to trace elements in the float-sink experiments (Querol et al. 2001; Reed et al. 2001).The deviations from the balance calculations of Co, $\mathrm{Hg}, \mathrm{Pb}, \mathrm{Sb}$ are slightly large.

As shown in Table 4, As, $\mathrm{Ba}, \mathrm{Cr}, \mathrm{Pb}$ are enriched in the high density products, which accords to the behavior of ash yield in coal preparation process. So those trace elements are likely distributed in minerals. The concentrations of $\mathrm{Hg}$ and $\mathrm{Mn}$ decrease as density increase, and significantly elevate in the heaviest fraction. $\mathrm{Cd}, \mathrm{Co}, \mathrm{Ni}, \mathrm{Sb}, \mathrm{Se}$ may be evenly distributed between the minerals and organic matter as the concentrations of those elements do not vary greatly across the density fractions. It is worth noting that the particle size and the degree of mineral liberation achieved in sample preparation also influent the tendency. 
Table 4 Maceral compositions and concentrations of 12 trace elements in the products from the float-sink experiments

\begin{tabular}{|c|c|c|c|c|c|c|c|c|c|c|}
\hline \multirow{2}{*}{\multicolumn{2}{|c|}{$\frac{\text { Size grade }(\mathrm{mm})}{\text { Density }\left(\mathrm{g} / \mathrm{cm}^{3}\right)}$}} & \multicolumn{6}{|l|}{$3-0.5$} & $<0.5$ & \multirow{3}{*}{$\begin{array}{l}\text { Raw } \\
\text { coal }\end{array}$} & \multirow{3}{*}{$R(\%)$} \\
\hline & & -1.30 & $1.3-1.4$ & $1.4-1.5$ & $1.5-1.6$ & $1.6-1.8$ & +1.80 & & & \\
\hline \multicolumn{2}{|c|}{ Yield of product (\%) } & 38.24 & 20.14 & 19.22 & 8.60 & 7.01 & 6.79 & & & \\
\hline \multirow{2}{*}{$\begin{array}{l}\text { Coal } \\
\text { quality }\end{array}$} & $A_{d}(\%)$ & 8.16 & 11.94 & 23.06 & 35.17 & 47.89 & 69.98 & 31.50 & 25.56 & 92.68 \\
\hline & $\mathrm{S}_{\mathrm{t}, \mathrm{d}}(\%)$ & 0.54 & 0.58 & 0.61 & 0.60 & 0.48 & 0.72 & 0.57 & 0.56 & 102.41 \\
\hline \multirow{7}{*}{ 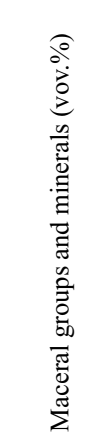 } & Vitrinite & 86.3 & 83.3 & 77.7 & 66.4 & 51.1 & 15.9 & n.d. & 76.3 & n.d. \\
\hline & Inertinite & 6.5 & 7.6 & 6.6 & 9.3 & 10.7 & 23.8 & n.d. & 6.1 & n.d. \\
\hline & Liptinite & 2.6 & 2.3 & 1.7 & 1.3 & 3.9 & 0.0 & n.d. & 2.1 & n.d. \\
\hline & $\begin{array}{l}\text { Clay } \\
\text { mineral }\end{array}$ & 4.5 & 6.4 & 13.6 & 22.6 & 33.5 & 52.5 & n.d. & 15.1 & n.d. \\
\hline & Pyrite & 0.0 & 0.0 & 0.1 & 0.2 & 0.3 & 1.4 & n.d. & 0.1 & n.d. \\
\hline & Quartz & 0.0 & 0.4 & 0.2 & 0.1 & 0.3 & 4.6 & n.d. & 0.1 & n.d. \\
\hline & Carbonates & 0.1 & 0.0 & 0.1 & 0.1 & 0.2 & 1.8 & n.d. & 0.2 & n.d. \\
\hline \multirow{12}{*}{ 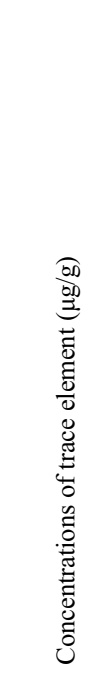 } & As & 15.70 & 16.10 & 14.80 & 21.80 & 33.80 & 58.60 & 1.62 & 23.2 & 67.45 \\
\hline & $\mathrm{Ba}$ & 130 & 126 & 152 & 165 & 180 & 287 & 331 & 248 & 78.88 \\
\hline & $\mathrm{Be}$ & 0.68 & 1.20 & 1.74 & 2.16 & 2.43 & 1.85 & 1.36 & 1.47 & 90.37 \\
\hline & $\mathrm{Cd}$ & 0.057 & 0.060 & 0.077 & 0.062 & 0.067 & 0.071 & 0.061 & 0.09 & 69.89 \\
\hline & $\mathrm{Co}$ & 5.71 & 8.84 & 6.86 & 6.64 & 6.70 & 6.17 & 4.14 & 3.14 & 194.03 \\
\hline & $\mathrm{Cr}$ & 7.92 & 10.3 & 12.2 & 12.6 & 15.2 & 22.9 & 16.8 & 18.5 & 67.90 \\
\hline & $\mathrm{Hg}$ & 0.088 & 0.027 & 0.024 & 0.038 & 0.12 & 1.50 & 0.014 & 0.25 & 48.59 \\
\hline & $\mathrm{Mn}$ & 123 & 78.0 & 82.7 & 72.5 & 57.7 & 852 & 212 & 186 & 87.66 \\
\hline & $\mathrm{Ni}$ & 3.87 & 4.11 & 4.55 & 4.92 & 4.63 & 4.42 & 5.19 & 4.56 & 98.02 \\
\hline & $\mathrm{Pb}$ & 14.7 & 19.0 & 25.9 & 25.5 & 26.3 & 54.9 & 18.5 & 9.08 & 234.24 \\
\hline & $\mathrm{Sb}$ & 8.06 & 10.20 & 5.80 & 6.01 & 6.48 & 8.02 & 1.34 & 2.97 & 207.50 \\
\hline & $\mathrm{Se}$ & 1.08 & 1.00 & 0.22 & 0.22 & 0.68 & 1.00 & 0.37 & 1.00 & 68.60 \\
\hline
\end{tabular}

Notes

Yield of product between 3 and $0.5 \mathrm{~mm}$ was $75.04 \%$ and that of $<0.5 \mathrm{~mm}$ was $24.96 \%$

The balance calculations for the maceral groups are based on volume fraction

n.d. not-detected

The concentrations in fines below $0.5 \mathrm{~mm}$ behavior differently compared to that in the raw coal. The concentrations of As and $\mathrm{Hg}$ are remarkably lower than those in raw coal while that of $\mathrm{Pb}$ remarkably higher. The concentrations of $\mathrm{Sb}$ and Se are less than half of those in the raw coal. The concentrations of $\mathrm{Be}, \mathrm{Cd}$ and $\mathrm{Cr}$ are relatively lower than those in raw coal while those of $\mathrm{Ba}, \mathrm{Co}, \mathrm{Mn}$ and Ni relatively higher.

The concentrations of trace elements in the products of the different density fractions are shown in Fig. 7. The concentrations of $\mathrm{Mn}$ and $\mathrm{Hg}$ increase with the fraction density. The concentrations of $\mathrm{Ba}$ and $\mathrm{Cr}$ have the same tend, as do $\mathrm{As}$ and $\mathrm{Pb}$. The contents of $\mathrm{Be}$ and $\mathrm{Ni}$ are almost constant as the density change. This is also the case of Co and Sb.

\subsection{Occurrence of trace elements in No.14 coal from Huolinhe mine}

(1) Correlation analyses.

The correlation coefficients between the concentrations of trace elements and the organic matter, the minerals, the ash yield, and the sulfur content based on linear 

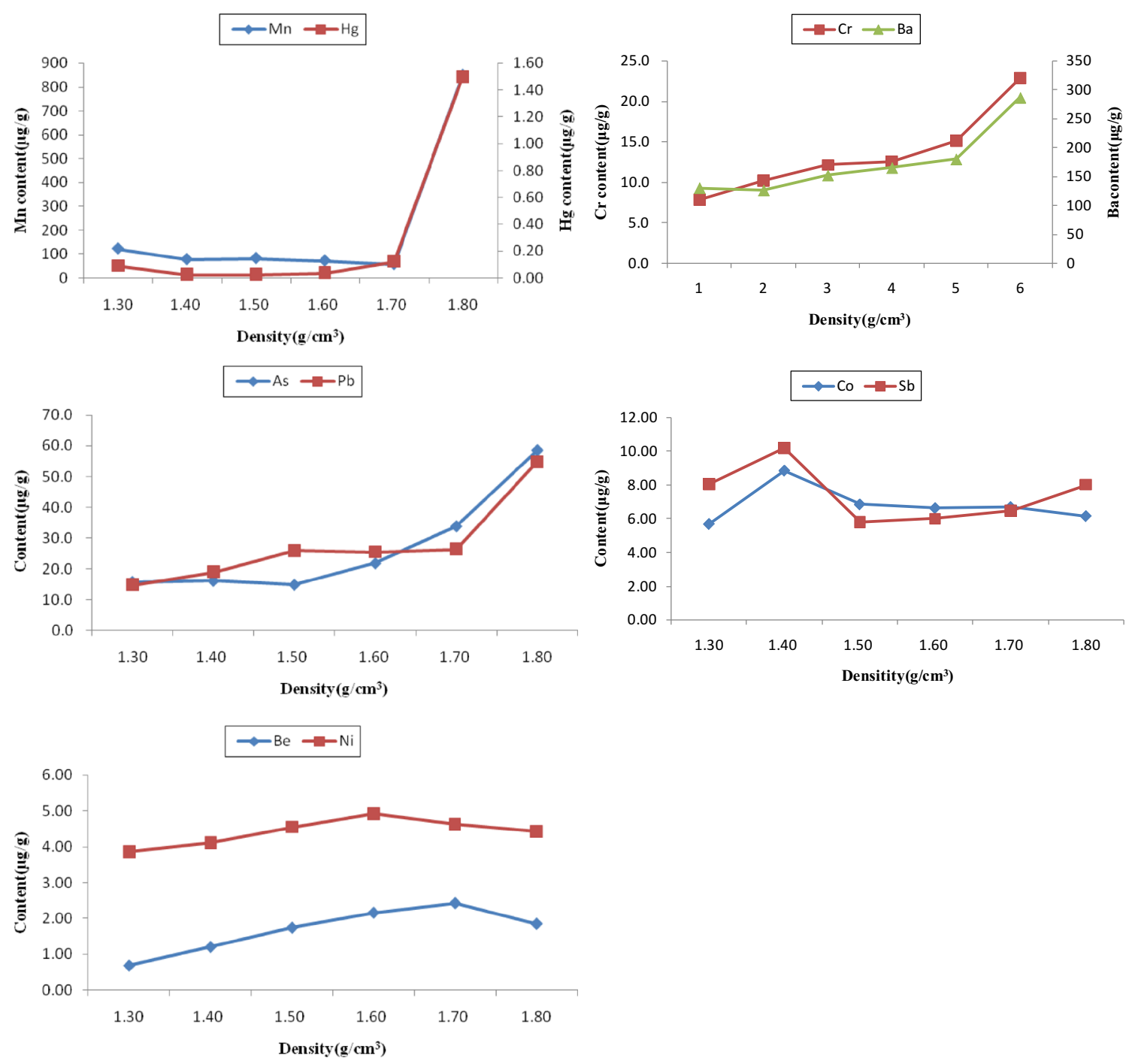

Fig. 7 Variations of trace element concentrations for the products of different densities of the No.14 coal in the Huolinhe mine

regressions are listed in Table 5. The relative proportions of trace elements, organic matter, clay minerals, pyrite, quartz and carbonates in the 6 products of different densities that were obtained from the float-sink experiments, the raw coal and the fines of less than $0.5 \mathrm{~mm}$ were used to calculate the correlation coefficients. A significant negative correlation exists between As and the proportion of organic matter, at a confidence level of 95\% (Critical correlation coefficient $R=0.7068$ ). This is also the case of $\mathrm{Pb}, \mathrm{Be}, \mathrm{Cr}$. A significant positive correlation was found between $\mathrm{Pb}$ and ash yield. This is also the case of $\mathrm{Cr}, \mathrm{As}, \mathrm{Hg}, \mathrm{Mn}$. A positive correlation was found between $\mathrm{Mn}$ and sulfur, which is also noted for $\mathrm{Hg}$ and $\mathrm{Pb}$. Significant positive correlations occur between As and the four mineral groups listed in Table 5. This is also the case of $\mathrm{Pb}$. A significant positive correlation is noted between $\mathrm{Hg}$ and pyrite, quartz, and carbonates, but no correlation between $\mathrm{Hg}$ and the clay minerals. This is also the case of $\mathrm{Mn}$ and $\mathrm{Cr}$. A significant positive correlation is noted between $\mathrm{Be}$ and clay minerals, but no correlation appears between $\mathrm{Be}$ and pyrite, quartz or the carbonates. No correlation occurs to $\mathrm{Cd}$ and the organic matter or any mineral component. This is also the case of $\mathrm{Co}, \mathrm{Ni}, \mathrm{Sb}$ and $\mathrm{Se}$.

The correlation coefficients of the trace elements are listed in Table 6. Significant positive correlations are found among $\mathrm{As}, \mathrm{Hg}, \mathrm{Pb}, \mathrm{Mn}, \mathrm{Cr}$, which indicates those elements may have similar modes of occurrences. Poor correlation coefficients are found among $\mathrm{Co}, \mathrm{Cd}, \mathrm{Ni}, \mathrm{Sb}, \mathrm{Se}$ and other elements. A significant positive correlation lies between Co and $\mathrm{Sb}$. Negative correlation lie between those two elements and Ba. A significant positive correlation lie between $\mathrm{Ni}$ and $\mathrm{Ba}$ while negative correlation lie between $\mathrm{Ni}$ and $\mathrm{Sb}, \mathrm{Se}$. $\mathrm{As}, \mathrm{Hg}, \mathrm{Pb}, \mathrm{Mn}, \mathrm{Cr}$ are mainly enriched in minerals while $\mathrm{Co}, \mathrm{Cd}, \mathrm{Ni}, \mathrm{Sb}, \mathrm{Se}$ are evenly distributed in organic matters and minerals according to the correlation analyses 
Table 5 Correlation coefficients showing relationships between trace elements and organic matter, minerals, ash and sulfur

\begin{tabular}{llllcrcr}
\hline Element & $A_{\mathrm{d}}$ & $\mathrm{S}_{\mathrm{t}, \mathrm{d}}$ & Organic matter & Clay minerals & Pyrite & Quartz & Carbonates \\
\hline $\mathrm{As}$ & 0.8079 & 0.5077 & -0.8877 & 0.8458 & 0.9750 & 0.9226 \\
$\mathrm{Ba}$ & 0.5667 & 0.3395 & -0.6789 & 0.6400 & 0.7809 & 0.7409 & 0.9444 \\
$\mathrm{Be}$ & 0.6960 & 0.0336 & -0.7717 & 0.8189 & 0.4303 & 0.2054 \\
$\mathrm{Cd}$ & 0.1844 & 0.1398 & -0.1455 & 0.1469 & 0.1011 & 0.0777 & 0.2198 \\
$\mathrm{Co}$ & -0.0764 & 0.0943 & 0.0386 & -0.0383 & -0.0444 & 0.0073 & -0.1327 \\
$\mathrm{Cr}$ & 0.8302 & 0.5010 & -0.7666 & 0.7341 & 0.8192 & 0.7628 \\
$\mathrm{Hg}$ & 0.7771 & 0.7610 & -0.7008 & 0.6323 & 0.9464 & 0.9836 \\
$\mathrm{Mn}$ & 0.7393 & 0.8019 & -0.6419 & 0.5684 & 0.9208 & 0.9777 & 0.9939 \\
$\mathrm{Ni}$ & 0.3780 & 0.0108 & -0.5254 & 0.5749 & 0.2188 & 0.0072 \\
$\mathrm{~Pb}$ & 0.8397 & 0.7408 & -0.8307 & 0.7863 & 0.9364 & 0.9164 & 0.0437 \\
$\mathrm{Sb}$ & -0.0627 & 0.1835 & 0.0977 & -0.1378 & 0.1115 & 0.2468 \\
$\mathrm{Se}$ & -0.0573 & 0.0121 & 0.1644 & -0.2199 & 0.1297 & 0.2747 & 0.1290 \\
\hline
\end{tabular}

Table 6 Correlation coefficients for the trace elements in the No.14 coal from the Huolinhe mine

\begin{tabular}{|c|c|c|c|c|c|c|c|c|c|c|c|c|}
\hline Element & As & $\mathrm{Ba}$ & $\mathrm{Be}$ & $\mathrm{Cd}$ & $\mathrm{Co}$ & $\mathrm{Cr}$ & $\mathrm{Hg}$ & $\mathrm{Mn}$ & $\mathrm{Ni}$ & $\mathrm{Pb}$ & $\mathrm{Sb}$ & $\mathrm{Se}$ \\
\hline As & 1.0000 & & & & & & & & & & & \\
\hline $\mathrm{Ba}$ & 0.1694 & 1.0000 & & & & & & & & & & \\
\hline $\mathrm{Be}$ & 0.4640 & 0.1169 & 1.0000 & & & & & & & & & \\
\hline $\mathrm{Cd}$ & 0.2446 & 0.2637 & 0.2326 & 1.0000 & & & & & & & & \\
\hline Co & 0.1323 & -0.6738 & 0.1540 & -0.4884 & 1.0000 & & & & & & & \\
\hline $\mathrm{Cr}$ & 0.6240 & 0.8337 & 0.4245 & 0.5215 & -0.4582 & 1.0000 & & & & & & \\
\hline $\mathrm{Hg}$ & 0.8787 & 0.4628 & 0.1762 & 0.2132 & -0.0574 & 0.7472 & 1.0000 & & & & & \\
\hline $\mathrm{Mn}$ & 0.7575 & 0.5927 & 0.0723 & 0.1578 & -0.1469 & 0.7668 & 0.9755 & 1.0000 & & & & \\
\hline $\mathrm{Ni}$ & -0.1988 & 0.6184 & 0.5467 & 0.1266 & -0.3899 & 0.4334 & -0.1298 & -0.0366 & 1.0000 & & & \\
\hline $\mathrm{Pb}$ & 0.8098 & 0.2805 & 0.4573 & -0.0464 & 0.3008 & 0.5679 & 0.8463 & 0.8122 & 0.0400 & 1.0000 & & \\
\hline $\mathrm{Sb}$ & 0.3944 & -0.6761 & -0.1073 & -0.3949 & 0.8335 & -0.3778 & 0.2294 & 0.1089 & -0.7741 & 0.3400 & 1.0000 & \\
\hline $\mathrm{Se}$ & 0.3878 & -0.0556 & -0.4841 & 0.0629 & -0.0402 & 0.0953 & 0.4030 & 0.3466 & -0.7449 & -0.0027 & 0.4488 & 1.0000 \\
\hline
\end{tabular}

Table 7 Theoretical trace element contents in the organic matters and in the minerals of No.14 coal from Houlinhe, calculated value ( $\mu \mathrm{g} / \mathrm{g}$ )

\begin{tabular}{|c|c|c|c|c|c|}
\hline \multirow[t]{2}{*}{ Element } & \multicolumn{2}{|l|}{ Component } & \multicolumn{3}{|c|}{ Significance testing } \\
\hline & Organic matter & Minerals & $\mathrm{R}$ & $\mathrm{F}$ & Significance \\
\hline As & 4.63 & 72.99 & 0.9403 & 19.09 & Significant \\
\hline $\mathrm{Ba}$ & 114.75 & 333.34 & 0.772 & 3.70 & Relatively- significant \\
\hline $\mathrm{Be}$ & 1.00 & 2.93 & 0.6960 & 2.82 & Relatively- significant \\
\hline $\mathrm{Cd}$ & 0.06 & 0.08 & 0.4812 & 0.75 & Non-significant \\
\hline Co & 6.89 & 5.49 & 0.214 & 0.12 & Non-significant \\
\hline $\mathrm{Cr}$ & 8.22 & 28.21 & 0.8302 & 6.65 & Significant \\
\hline $\mathrm{Hg}$ & -0.37 & 1.61 & 0.7771 & 4.57 & Significant \\
\hline $\mathrm{Mn}$ & -103.73 & 880.92 & 0.7393 & 3.62 & Relatively- significant \\
\hline $\mathrm{Ni}$ & 4.28 & 5.07 & 0.378 & 0.5 & Non-significant \\
\hline $\mathrm{Pb}$ & 8.52 & 63.49 & 0.8829 & 8.84 & Significant \\
\hline $\mathrm{Sb}$ & 8.06 & 6.13 & 0.2710 & 0.16 & Non-significant \\
\hline $\mathrm{Se}$ & 0.73 & 0.62 & 0.057 & 0.01 & Non-significant \\
\hline
\end{tabular}


Table 8 Organic affinity of the trace elements in No.14 coal from Huolinhe mine

\begin{tabular}{lllllllllllll}
\hline Element & $\mathrm{As}$ & $\mathrm{Ba}$ & $\mathrm{Be}$ & $\mathrm{Cd}$ & $\mathrm{Co}$ & $\mathrm{Cr}$ & $\mathrm{Hg}$ & $\mathrm{Mn}$ & $\mathrm{Ni}$ & $\mathrm{Pb}$ & $\mathrm{Sb}$ & $\mathrm{Se}$ \\
\hline$A_{\mathrm{o}}$ & 14.86 & 34.44 & 50.64 & 71.01 & 84.18 & 33.08 & - & - & 69.87 & 29.82 & 97.36 & 54.34 \\
\hline
\end{tabular}
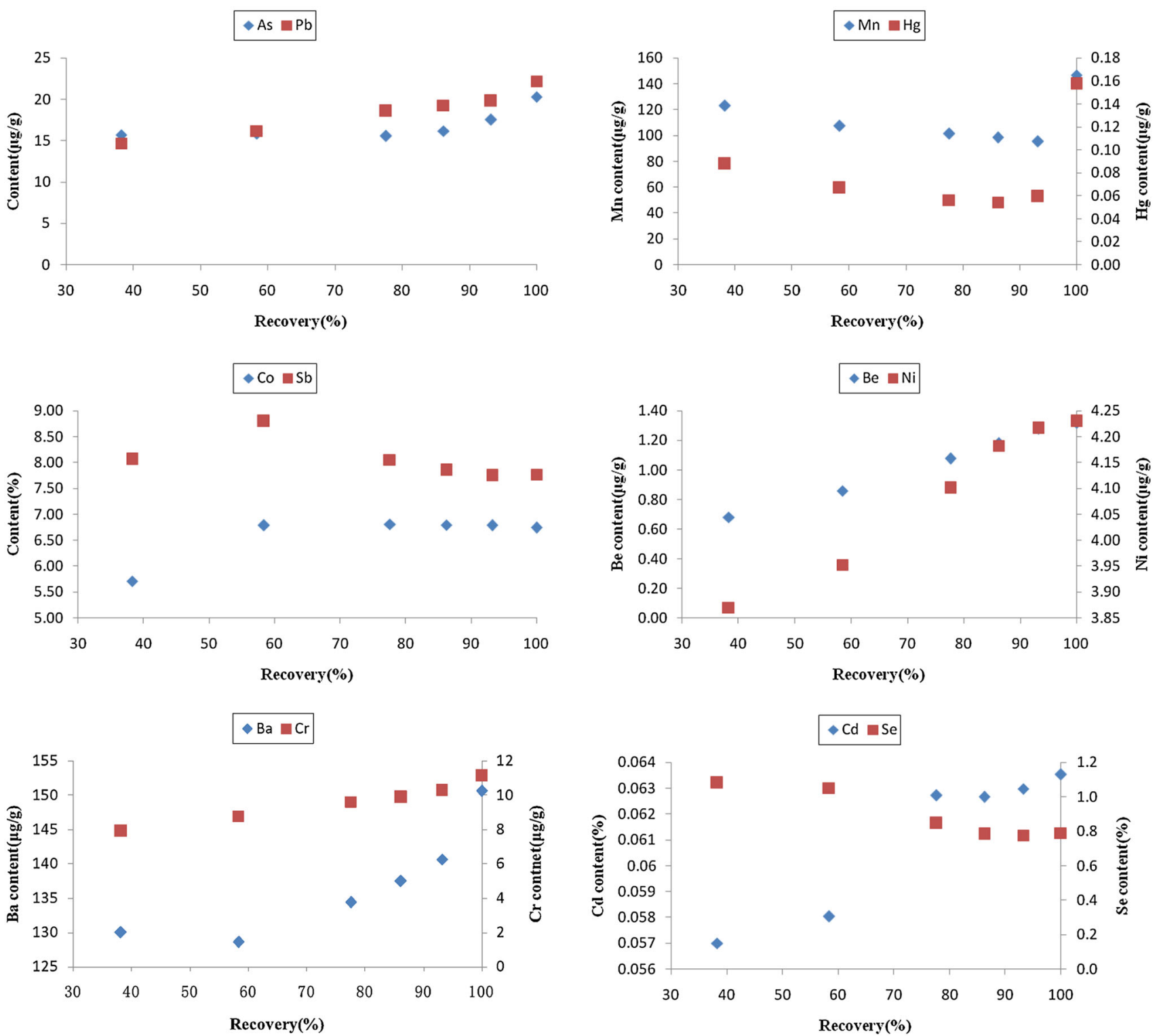

Fig. 8 Washability curves for trace elements in the No.14 coal from the Huolinhe mine

of the trace elements and between the trace elements and the maceral groups.

(2) Inferred concentrations of trace elements in the organic matter and minerals.

An attempt has been made to estimate the trace element content of the organic matter and of the minerals using the results of the float-sink experiments and the statistical methods. The inferred concentration of trace elements in the organic matter and the minerals are listed in Table 7. In the significance testing, the significance divisions $\mathrm{F}_{0.05}(2, n$ 3) is 5.79 (sample number is 8) at a confidence level of $95 \%$ from an $\mathrm{F}$ test. As, $\mathrm{Cr}, \mathrm{Hg}, \mathrm{Mn}, \mathrm{Pb}$ are obviously concentrated in the minerals with low concentrations found in organic matters. There are similar contents of $\mathrm{Cd}$ in minerals and in organic matters. Also, these come to the cases of $\mathrm{Co}, \mathrm{Ni}, \mathrm{Sb}, \mathrm{Se}$. Those elements are evenly distributed in minerals and organic matters (No significant 
Table 9 Theoretical removability of trace elements in No.14 coal from Huolinhe mine (Recovery of clean coal was $58.38 \%$ at a separation density of $1.40 \mathrm{~g} / \mathrm{cm}^{3}$ )

\begin{tabular}{lllllllllllll}
\hline Element & $\mathrm{As}$ & $\mathrm{Ba}$ & $\mathrm{Be}$ & $\mathrm{Cd}$ & $\mathrm{Co}$ & $\mathrm{Cr}$ & $\mathrm{Hg}$ & $\mathrm{Mn}$ & $\mathrm{Ni}$ & $\mathrm{Pb}$ & $\mathrm{Sb}$ & $\mathrm{Se}$ \\
\hline Theoretical removal rate $(\%)$ & 60.41 & 69.92 & 66.09 & 47.02 & 41.59 & 72.60 & 84.46 & 66.49 & 49.72 & 57.70 & 34.30 & 38.96 \\
\hline
\end{tabular}

correlation from an $F$ test). The Be and Ba contents are higher in minerals than that in organic matters. Concentrated in minerals and low contents are detected in organic matters, $\mathrm{Hg}$ and $\mathrm{Mn}$ show negative values in calculations.

(3) Organic affinities of the trace elements in No.14 coal from Huolinhe mine.

The organic affinities of the trace elements in No.14 coal are listed in Table 8. The values of $\mathrm{Cd}, \mathrm{Co}, \mathrm{Pb}, \mathrm{Sb}$ in the raw coal were obtained from weighted mean values of those elements in the different density products. As shown in Table $8, \mathrm{As}, \mathrm{Pb}, \mathrm{Cr}, \mathrm{Ba}$ are mainly integrated with inorganics and have low organic affinities while $\mathrm{Sb}, \mathrm{Co}, \mathrm{Cd}, \mathrm{Ni}$, Se are mainly organically associated and have high organic affinities. It is worth noting that trace elements with high organic affinity do not necessary occur in the organic matter itself, because some trace elements are also present in fine grained minerals within the organic-rich particles.

\subsection{Removability of trace elements during coal preparation in No.14 coal}

The washability curves of the trace elements in No.14 coal during coal preparation are shown in Fig. 8. The theoretical removabilities of the trace elements are listed in Table 9. The values of $\mathrm{Cd}, \mathrm{Co}, \mathrm{Pb}, \mathrm{Sb}$ in raw coal were obtained from the weighted mean values of those elements in the different density products.

The washability curves of $\mathrm{Mn}$ and $\mathrm{Hg}$ are similar, which are also the cases of $\mathrm{Sb}$ and $\mathrm{Co}, \mathrm{Be}$ and $\mathrm{Ni}, \mathrm{Ba}$ and $\mathrm{Cr}$. High removal rates can be achieved for most elements in this coal preparation procedure because sharp washability curves were obtained. The elements with flat washability curves, i.e. $\mathrm{Sb}, \mathrm{Co}, \mathrm{Se}$, are even-distributed in organics and in mineral matters and can't be effectively removed in coal preparation. The washabilities of trace elements in an operating coal preparation plant would also depend on the particle size of the feed coal and the efficiency of the separation method(s) used.

A poor washability was obtained for the No.14 coal when the ash yield of the cleaned coal was below $10 \%$. The recovery of trace elements is closely related to the washablity of that element, as shown in Table 9. Most trace elements are closely related to minerals and have potential for high removability from No.14 coal, which is also

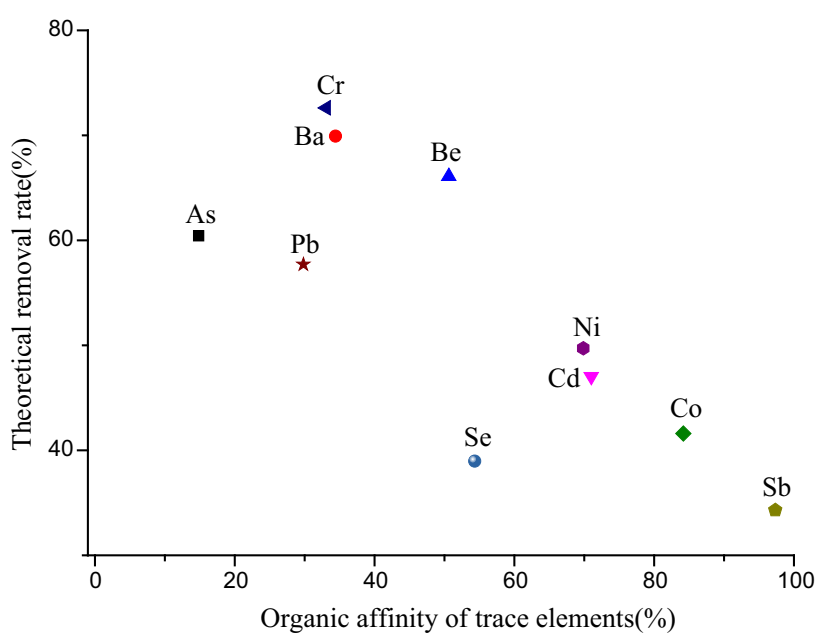

Fig. 9 Relationship between organic affinity and theoretical trace element removal rate in the No.14 coal from the Huolinhe mine

shown by the correlation analyses and the calculations of theoretical concentrations of trace elements in organic matter and minerals. The relationships between organic affinity and the theoretical removal rate of trace elements in No.14 coal from Huolinhe mine are shown in Fig. 9. High removability of $\mathrm{Hg}, \mathrm{Cr}, \mathrm{Ba}, \mathrm{Mn}, \mathrm{Be}, \mathrm{As}, \mathrm{Pb}$ are suggested, while organic-associated elements like $\mathrm{Sb}$, Se, $\mathrm{Co}, \mathrm{Cd}, \mathrm{Ni}$ have poor removabilities.

\section{Conclusions}

Optical microscope, SEM studies and chemical analyses were used to identify the characteristics of the minerals, the major and trace element concentrations of the No.14 coal from the Huolinhe mine. The distribution of trace elements in the organic and in mineral components, as well as the organic affinity and removability of the trace elements were also discussed.

(1) A high mineral content, dominated by clay minerals, was found for the No.14 coal from the Huolinhe mine. The proportion of quartz is relatively high while those of pyrite and hematite are low. The different $\mathrm{Al}$ contents of kaolinite and illite have caused low contents of $\mathrm{Al}_{2} \mathrm{O}_{3}$.

(2) The concentrations of trace elements in Huolinhe mine are relatively low, which is beneficial to coal 
processing and utilization. The concentrations of As, $\mathrm{Sb}$ and $\mathrm{Hg}$ are relatively high compared to the average values for Chinese coals.

(3) $\mathrm{As}, \mathrm{Cr}, \mathrm{Hg}, \mathrm{Mn}, \mathrm{Pb}$ are mainly concentrated in the minerals, while $\mathrm{Cd}, \mathrm{Co}, \mathrm{Ni}, \mathrm{Sb}$, Se are mainly evenly distributed between the organic and mineral-rich components. $\mathrm{Be}$ and $\mathrm{Ba}$ are mainly distributed in minerals with some in the organic matter.

(4) High removal rates can be achieved for most elements in this coal preparation procedure due to their low organic affinities, except for $\mathrm{Sb}, \mathrm{Se}, \mathrm{Co}, \mathrm{Cd}$ and $\mathrm{Ni}$, so it is viable to lower the concentrations of trace elements in coal preparation. The removabilities of trace elements in an operating coal preparation plant would also depend on the particle size of the feed coal and the efficiency of the separation methods used.

Acknowledgements The research leading to these results has received funding from the Major State Basic Research Development Program of China (Grant agreement number 2016YFB0600301). Special thanks are given to the anonymous reviewers for useful suggestions and comments.

Open Access This article is distributed under the terms of the Creative Commons Attribution 4.0 International License (http://crea tivecommons.org/licenses/by/4.0/), which permits unrestricted use, distribution, and reproduction in any medium, provided you give appropriate credit to the original author(s) and the source, provide a link to the Creative Commons license, and indicate if changes were made.

\section{References}

Bai XF(2003) The distributions, modes of occurrence and volatility of trace elements in coals of China. Doctor's Thesis, Coal Research Institute

Bai XF, Li WH, Yang TR (2002) Study on distribution and modes of occurrence of trace elements in Datong Jurassic 10-11\# Coal. Coal Convers 25(4):92-95

Bai XF, Li WH, Chen YF, Jiang Y (2007) The general distributions of trace elements in Chinese coals. Coal Qual Technol 1:1-4

Bai XF, Wang Y, Li WH (2014) Mineralogy, distribution, Occurrence and removability of trace elements during the coal preparation of No.6 coal from Heidaigou mine. Int $\mathrm{J}$ Coal Sci Technol 1(4):402-420

Bai XF, Li WH, Wang Y, Ding H (2017) The distribution and occurrence of mercury in Chinese coals. Int J Coal Sci Technol 4(2):172-182

Dai SF, Ren DY, Tang YG, Yue M, Hao LM (2005) Concentration and distribution of elements in Late Permian coals from western Guizhou Province, China. Int J Coal Geol 61:119-137

Dai SF, Ren DY, Chou CL, Finkelman RB, Seredin VV, Zhou YP (2012) Geochemistry of trace elements in Chinese coals: a review of abundances, genetic types, impacts on human health, and industrial utilization. Int J Coal Geol 94:3-21

Equeenuddin Sk Md, Tripathy S, Sahoo PK, Ranjan A (2016) Geochemical characteristics and mode of occurrence of trace elements in coal at West Bokaro coalfield. Int J Coal Sci Technol 3(4):399-406

Finkelman RB (1994) Modes of occurrence of potentially hazardous elements in coal: levels of confidence. Fuel Process Technol 39(1-3):21-34

Gluskoter HJ, Ruch RR, Miller WG, Cahill RA, Dreher GB, Kuhn JK (1977) Trace elements in coal: occurrence and distribution. Ill State Geol Surv Circ 499:154

Ketris MP, Yudovich YE (2009) Estimations of Clarkes for carbonaceous biolithes: world averages for trace element contents in black shales and coals. Int J Coal Geol 78:135-148

Klika Z, Kolonaznik I (2000) New concept for the calculation of the trace element affinity in coal. Fuel 79:659-670

Klika Z, Weiss Z, Roubicek V (1997) Calculation of element distributions between inorganic and organic parts of coal. Fuel 76(14/15):1537-1544

Li ZS, Ward CR, Gurba LW (2010) Occurrence of non-mineral inorganic elements in macerals of low-rank coals. Int J Coal Geol 81:242-250

Mao JH, Xu HL (1999) Prediction and evaluation of coal resources in China. Science Press, Beijing

Martinez-Tarazona MR, Spears DA, Tascon JMD (1992) Organic affinity of trace elements in Asturian bituminous coals. Fuel 71:909-917

Oliveira ML, Ward CR, Sampaio CH, Querol X, Cutruneo CM, Taffarel SR, Silva LF (2013) Partitioning of mineralogical and inorganic geochemical components of coals from Santa Catarina, Brazil, by industrial beneficiation processes. Int $\mathrm{J}$ Coal Geol 116-117:75-92

Pires M, Fiedler H, Teixeira EC (1997) Geochemical distribution of trace elements in coal: modeling and environmental aspects. Fuel 76(14/15):1425-1437

Querol X, Klika Z, Weiss Z, Finkelman RB, Alastueya A, Juana R, López-Solera A, Plana F, Kolker A, Chenery SRN (2001) Determination of element affinities by density fractionation of bulk coal samples. Fuel 80:83-96

Reed GP, Ergudenler A, Grace JR, Watkinson AP, Herod AA, Dugwell D, Kandiyoti R (2001) Control of gasifier mercury emissions in a hot gas filter: the effect of temperature. Fuel 80(5):623-634

Ren DY, Zhao FH, Wang YQ, Yang SJ (1999) Distributions of minor and trace elements in Chinese coals. Int J Coal Geol 40:109-118

Senior CL, Zeng T, Che J, Ames MR, Sarofim AF, Olmez I, Huggins FE, Shah N, Huffman GP, Kolker A, Mroczkowski S, Palmer C, Finkelman RB (2000) Distribution of trace elements in selected pulverized coals as a function of particle size and density. Fuel Process Technol 63(2-3):215-241

Solari JA, Fiedler H, Schneider CL (1989) Modelling of the distribution of trace elements in coal. Fuel 68:536-539

Song DY, Zhang XK, Zhang JY, Zheng CG (2010) Migration characteristics of hazardous trace elements in coal in the process of flotation. J China Coal Soc 35(7):1170-1176

Tang YG, Chang CX, Zhang YZ (2005) Migration and distribution of fifteen toxic trace elements during the coal washing of the Kailuan Coalfield, Hebei Province. Geochimica 34(4):366-372

Wagner NJ, Tlotleng MT (2012) Distribution of selected trace elements in density fractionated Waterberg coals from South Africa. Int J Coal Geol 94:225-237

Wang L, Li J (2007) Migration law of harmful elements in Pingshuo coal during coal preparation. Coal Sci Technol 35(6):77-79

Ward CR (2002) Analysis and significance of mineral matter in coal seams. Int J Coal Geol 50:135-168 